Огляди літератури, оригінальні дослідження, погляд на проблему, ювілеї

УДК 616.71-007.234-037:[616.37-002.2 +616.12-008.331.1]-078

DOI 10.11603/1811-2471.2018.v0.i2.8585

\title{
АСОЦІАЦІЯ МЕТАБОЛІЧНИХ І ГЕНЕТИЧНИХ МАРКЕРІВ РИЗИКУ РОЗВИТКУ ОСТЕОПЕНІЧНИХ СТАНІВ ПРИ ПОЄДНАННІ ХРОНІЧНОГО ПАНКРЕАТИТУ І ГІПЕРТОНІЧНОї ХВОРОБИ
}

\author{
ФЛ. М. Пасієшвілі', Т. І. В'юн', О. А. Лазуткіна² \\ Харківський національний медичний університет ${ }^{1}$, \\ Харківська міська багатопрофільна лікарня № $18^{2}$
}

РЕЗЮМЕ. При обстеженні 70 пацієнтів з хронічним панкреатитом (ХП) і гіпертонічною хворобою (ГП) проведені дослідження ролі гена рецепторів вітаміну D у перебігу цих захворювань. Встановлено, що коморбідність нозологічних форм частіше спостерігалася у осіб з наявністю В-алеля поліморфізму гена VDR (84,3 \%), на відміну від контролю (75,7 \%) і групи пацієнтів з ізольованим ХП (77,5 \%). Також при ХП і ГХ частіше формувалися остеопоротичні зміни (27,3 \%), на відміну від групи порівняння, де таких хворих було 10 \%. Показані достовірні зміни показників вмісту остеокальцину, що мають залежність від поліморфізму гена VDR.

КлючОВІ СлОВА: хронічний панкреатит; гіпертонічна хвороба; ген рецепторів вітаміну D; остеокальцин.

Вступ. Гіпертонічна хвороба (ГХ) є однією 3 найбільш значущих медичних і соціальних проблем, що пов'язано як зі значним поширенням цієї нозологічної форми, так і з розвитком надважливих серцево-судинних катастроф $[5,9]$. За даними Центру медичної статистики МОЗ України, в 2014 році в країні зареєстровано понад 12 млн осіб зі стабільно підвищеним артеріальним тиском (АТ), що становить майже 30 \% дорослого населення [6]. ГХ розглядають як хворобу, якій притаманний мультифакторний механізм формування, в тому числі генетична схильність та вплив зовнішнього середовища $[4,14]$. Поєднання ГХ з іншими захворюваннями внутрішніх органів у зв'язку з системним ураженням судинної системи, як одним 3 факторів патогенезу, може сприяти погіршенню перебігу процесу, та, таким чином, негативно впливати на якість життя пацієнтів [1].

Одним із таких можливих несприятливих патологічних станів $\epsilon$ хронічний панкреатит (ХП). За поширеністю, ростом захворюваності, формуванням ускладнень, тимчасової втрати працездатності та причин виходу на інвалідність ХП займає передові місця, тому його розглядають як важливу соціально-економічну проблему [8]. Поєднання цих захворювань розглядають не тільки як збіг значної їх поширеності, а й визначають ряд факторів зовнішнього середовища, які можуть провокувати цю коморбідність, а саме - збільшення споживання алкоголю, куріння, хронічний стрес, зниження якості їжі та загального рівня життя [10].

Одним із несприятливих факторів поєднання $\ulcorner Х$ та ХП $\epsilon$ погіршення мінеральної щільності кісткової тканини (МЩКТ), тобто розвиток остеопоротичних станів $[2,7]$. Виникнення вторинного остеопорозу (ОП) пов'язують не тільки з порушенням процесів травлення, що призводить до зменшення всмоктування вітаміну D, остеоасоційованих хімічних макроелементів (кальцій, фосфор, магній), їх перерозподілом в організмі і, таким чином, порушенням синтезу кісткової тканини [13]. Ці зміни відбуваються у присутності вітамін К-залежного неколагенового білка кісткової тканини - остеокальцину, який синтезують зрілі остеобласти. Його розглядають як чутливий індикатор метаболізму кісткової тканини [15].

Роль кальцію була встановлена в секреторному процесі підшлункової залози (ПЗ): надходження іонів кальцію і ферментів відбувається паралельно. Кальцій, який вивільнюється, запускає секрецію ферментів і відкриває канали для іонів $\mathrm{Ca}^{2+}, \mathrm{K}^{+}, \mathrm{Na}^{2+}$, наслідком чого $\epsilon$ деполяризація клітинних мембран [16]. У разі недостатнього надходження кальцію з кишечника ці потреби будуть поповнюватися надходженням макроелемента з депо - кісткової тканини. Одночасно при ХП виникає гіподинамія, яка також сприяє випаданню солей кальцію в осад, що в 72 \% випадків призводить до порушень функцій підшлункової залози. Існує і зворотний зв'язок: наявність кальцифікатів у протоці ПЗ може потенціювати розвиток ХП [12]. Тобто, дисбаланс кальцію в організмі може не тільки запустити патологічний процес у П3, формувати загострення захворювання і призводити до його прогресування, а й сприяти розвитку остеопорозу [11].

Підтримання гомеостазу кальцію $€$ важливим аспектом мінералізації кісткової тканини. Всмоктування кальцію відбувається в присутності вітаміну $D$, дія якого регулюється за допомогою гена рецепторів вітаміну D (VDR). Ген VDR розглядають як ген-кандидат, зміни в поліморфізмі якого $\epsilon$ предиктором формування остеопенічних станів $[3,15]$. Золотим стандартом серед маркерів кісткоутворення $\epsilon$ визначення вмісту остеокальцину, 
Огляди літератури, оригінальні дослідження, погляд на проблему, ювілеї

який має кальційзв'язувальну здатність та бере участь у мінералізації кістки [12].

Мета дослідження - встановити взаємозв'язок остеокальцину й гена рецепторів вітаміну D (VDR) у пацієнтів з коморбідністю ХП і ГХ та визначити їх вплив на формування вторинного остеопорозу.

Матеріал і методи дослідження. Для проведення дослідження було сформовано дві групи хворих: основна - 70 пацієнтів з сукупним перебігом ХП і ГХ, та група порівняння - 40 осіб, хворих на ізольований ХП. Склад груп не відрізнявся за віком - $(33,2 \pm 2,1)$ років (основна) та $(32,9 \pm 3,1)$ років (порівняння), і статтю (жінки склали $72,9 \%$ і $70 \%$

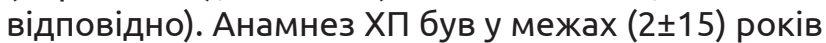
з інтерквартильним розмахом 4-7 (IP) років, з медіальною тенденцією 5 років. Анамнез ГХ коливався від 3 до 17 років з таким самим IK (4-8 років) та медіальною тенденцією 5 років.

Контрольні показники біохімічних та генетичних досліджень були отримані при дослідженні 70 практично здорових осіб, репрезентативних основній групі за віком та статтю.

Діагноз ГХ встановлювали з урахуванням рекомендацій Європейського товариства з артеріальної гіпертензії (ESH) (2009р.); рекомендацій робочої групи з артеріальної гіпертензії Української асоціації кардіологів із профілактики та лікування АГ (2012р.) з урахуванням класифікації ступеня та стадії АГ, ризику АГ (стратифікація ризику для оцінки прогнозу АГ).

Хронічний панкреатит верифікували за оцінкою скарг пацієнтів, даних анамнезу, результатів клініко-лабораторних та інструментальних методів дослідження, посилаючись на наказ МОЗ України № 271 від 13.06.2005 р. та наказ № 638 від 10.09.2014 р.

Визначення поліморфізму гена рецепторів вітаміну D проводили з використанням наборів фірми «Літех» (Росія) методом полімеразної ланцюгової реакції для ампліфікації в режимі реального часу з використанням флуоресцентних міток на шестиканальному аналізаторі Rotor-Gene ${ }^{\text {TM }} 6000$ ("Corbett Research», Australia).

Оцінку стану кісткової тканини проводили шляхом визначення рівня остеокальцину імуноферментним методом (набір реактивів Nordic Bio, Denmark).

Отримані дані обробляли методом аналізу таблиць сполученості за допомогою пакета програм Statistica. Результати представлені у вигляді середніх значень і їх стандартної помилки з урахуванням t-критерію Стьюдента (M $\pm m)$. Статистичну значущість результату оцінювали за допомогою критерію Пірсона $\chi$-квадрат (КХП).

Результати й обговорення. У пацієнтів основної групи впродовж анамнестично визначеної тривалості артеріальної гіпертензії (АГ) та особ- ливостей її перебігу визначали ГХ ІІ стадії та 2 ступеня з відносно м'яким перебігом захворювання. Екскреторна функція ПЗ за рівнем фекальної панкреатичної еластази-1 відповідала порушенню функції легкого ступеня у 27 осі6 (38,6 \%) основної групи і у 15 (37,5 \%) осіб групи порівняння, середнього ступеня тяжкості - у $43(61,4 \%)$ і 25 (62,5 \%) відповідно.

За результатами тестування поліморфного гена VDR пацієнти контролю були поділені на три групи. До 1 групи - носії bb-генотипу - увійшли 17 осіб (24,3 \%); до 2 - носії Вb-генотипу - 34 (48,6 \%), третя група була представлена 19 пацієнтами $(27,1 \%)$, носіями ВВ-генотипу. При ізольованому ХП генотип bb зустрічався у $22,5 \%$ випадків (9 осіб); Вb-генотип мали 42,5 \% (17 осіб) та ВВ - $35 \%$ (14 осіб). При поєднанні ХП і ГХ визначені відсоткові коливання в поліморфізмі даного гена були наступними: 15,7 \% (11 осіб), 32,9 \% (23 особи) та 51,4 \% (36 осіб) відповідно. Таким чином, переважна більшість хворих на ХП, обтяжений ГХ (84,3\%), мали патологічний В-алель, на відміну від групи порівняння, В якій означений В-алель реєстрували у $77,5 \%$ випадків.

Одним із етапів обстеження таких хворих було виявлення рівня остеокальцину та його співвідношення з патологічними алелями гена VDR. Доведено, що в присутності вітаміну D відбувається всмоктування кальцію в кишечнику, а його недостатність у харчовому раціоні та наявність кальційзалежних захворювань (ГX і ХП) можуть впливати на формування остеопенічних станів [16].

Виявлено, що вміст остеокальцину в групі контролю (70 практично здорових осі6) коливався від 14,7 до 26,0 нг/мл з медіаною 21,5 нг/мл.

У групі хворих на ізольований панкреатит середні показники вмісту остеокальцину дорівнювали $(26,1 \pm 0,8)$ нг/мл. Показники норми реєстрували у 27 пацієнтів $(67,5 \%)$ при наступному розподілі алелів: генотип bb мали 6 осіб (22,2 \%), ВB - 7 осіб (25,9\%), Вb - 14 осіб (51,9\%). Зниження рівня остеокальцину до $(17,1 \pm 0,4)$ нг/мл спостерігали у 4 хворих (10,0\%), один з яких в анамнезі мав перелом верхньої кінцівки. При цьому в 3 випадках визначали генотип ВВ та в одному - Вb. Підвищення вмісту остеокальцину $((37,9 \pm 0,8)$ нг/мл) було визначено у 9 хворих (22,5\%), двоє з яких раніше мали переломи кінцівок. Серед них генотип bb зустрічався у 33,3 \% випадків (3 особи); ВB - у $44,5 \%$ (4 особи) та Bb - у 22,2 \% (2 особи).

При поєднанні ХП і ГБ рівень остеокальцину в середньому по групі дорівнював $(22,1 \pm 0,64)$ нг/мл. Його нормальні значення мали 35 осіб (50\%) з наступними генотипами: bb - у 34,3 \% (12 осіб), Bb $37,1 \%$ (13 осіб) та ВВ - 28,6\% (10 осіб), з них 2 хворих мали переломи. Підвищений вміст остео- 
Огляди літератури, оригінальні дослідження, погляд на проблему, ювілеї

кальцину реєстрували у 12 хворих (17,1\%), 11 з них мали переломи в анамнезі; розподіл генотипів відповідав: Bb - у 83,3 \% (10 осіб) та ВB - у 16,7 \% (2 особи). Вміст остеокальцину нижче за норму визначали у 23 пацієнтів (32,9\%) з наступним поліморфізмом гена VDR: bb - у 8,7 \% (2 осо6и), Вb - у 17,4 \% (4 особи), ВВ - у 73,9\% (17 осіб), з них 16 хворих мали в минулому переломи.

Зміни в поліморфізмі гена VDR впливали на частоту ураження кістково-суглобової системи. Так, наявність переломів кісток в анамнезі була зареєстрована у 33 пацієнтів (30\% від 110 хворих на ХП), серед яких 29 (27,3\%) належали до основної групи та 4 (10 \%) - до групи порівняння. Залежність мала статистично значущий характер групи $\left(К Х П, ~ \chi^{2}=20,81, p<0,01\right)$. Означені результати були підставою до встановлення можливої залежності анамнестичних та клінічних показників від поліморфізму гена VDR. Так, було виявлено статистично значущу залежність у розподілі алелів гена VDR від групи (КХП, $\left.\chi^{2}=30,08, \mathrm{p}<0,01\right)$.

Висновки. При поєднанні хронічного панкреатиту і гіпертонічної хвороби відбувається збіль- шення кількості осіб з В-алелем гена VDR (84,3 \% випадків), носійство якого підвищує ризик формування остеопенічних станів.

Сукупний перебіг хронічного панкреатиту та гіпертонічної хвороби супроводжується коливаннями вмісту маркера кісткоутворення - остеокальцину, показники якого корелюють з поліморфізмом гена рецепторів вітаміну D.

Зниження вмісту остеокальцину в сироватці крові хворих з коморбідністю гіпертонічної хвороби та хронічного панкреатиту (32,9 \%) частіше відбувається на тлі несприятливого алеля В поліморфізму гена VDR (30\%).

Поєднання хронічного панкреатиту та гіпертонічної хвороби є підставою для ранньої діагностики остеопоротичних ускладнень.

Перспективи подальших досліджень полягають у визначенні вмісту інших біохімічних показників (кісткової фосфатази, тартратрезистентної кислої фосфатази) на процеси формування остеопенічних станів у поєднанні з генетичними абераціями.

\section{ЛІТЕРАТУРА}

1. Ацель Е. А. Эффективность образовательных программ в повышении компетентности врача в вопросах диагностики и лечения артериальной гипертензии / Е. А. Ацель // Справочник врача общей практики. - 2014. № 3. - С. 82-83.

2. Остеодефіцит і вплив супутньої патології на його глибину при хронічному панкреатиті / Л. С. Бабінець, О. С. Квасніцька, Л. М. Мігенько, О. Я. Пінкевич // Буковинський медичний вісник. - 2011. - Т. 15, № 2 (58). С. $183-185$.

3. Верткин А. Л. Остеопороз у пациентов с соматической патологией в зависимости от пола / А. Л. Верткин, Л. Ю. Моргунова, А. В. Наумова // Остеопороз и остеопатология. - 2007. - № 1. - С. 25-28.

4. Ена Л. М. Возраст как значимый компонент диагностики вторичных гипертензий / Л. М. Ена // Артериальная гипертензия. - 2015. - № 4. - С. 42-51.

5. Ковалева О. Н. Глюкометаболические нарушения и сердечно-сосудистый риск / О. Н. Ковалева // Українська школа ендокринології : матеріали 58-ої науково-практичної конференції з міжнародною участю. Харків, 5-6 червня 2014. - С. 63-73.

6. Коваленко В. М. Хвороби системи кровообігу як медико-соціальна і суспільно-політична проблема / В. М. Коваленко, В. М. Корнацький // Аналітично-статистичний посібник. - К., 2014. - 279 с.

7. Литовский И. А. Атеросклероз и гипертоническая болезнь. Вопросы патогенеза, диагностики и лечения / И. А. Литовский, А. В. Гордиенко. - М. : СпецЛит, 2013. -312 c.

8. Пасиешвили Л. М. Роль хронического панкреатита в нарушении метаболизма костной ткани и фор- мировании остеопороза / Л. М. Пасиешвили // Вісник ВДНЗУ «Українська медична стоматологічна академія» Актуальні проблеми сучасної медицини. - 2016. - Т. 16, вип. 4 (56). - С. 166-169.

9. Эффективность и безопасность комбинированной терапии на основе хлорталидона и атенолола в одной таблетке (тенорик) у пациентов с гипертонической болезнью: первые результаты всеукраинского научноисследовательского проекта trus / Ю. Н. Сиренко, И. М. Горбась, С. А. Андриевская [и др.] // Артериальная гипертензия - 2014. - № 6 (38). - С. 46-47.

10. Ткач С. М. Практические подходы к диагностике хронического панкреатита / С. М. Ткач // Сучасна гастроентерологія. - 2013. - № 1 (69). - С. 136-146.

11. Bergh J. P. Osteoporosis, frailty and fracture: implications for case finding and therapy / J. P. Bergh, T. A. Geel, P. P. Geusens // Nat. Rev. Rheumatol. - 2012. Vol. 8 (3). - P. 163-172.

12. Bernstein C. N. The pathophysiology of bone disease in gastrointestinal disease / C. N. Bernstein, W. D. Leslie // Eur. J. Gastroenterol. Hepatol. - 2013. - Vol. 15 (8). P. 857-864.

13. Dugga S. N. An association between abnormal bone turnover, systemic inflammation, and osteoporosis in patients with chronic pancreatitis: a case-matched study / S. N. Dugga, C. Purcell, M. Kilbane // Am. J. Gastroenterol. - 2015. - Vol. 110 (2). - P. 336- 344.

14. Kunes $\mathrm{J}$. The interaction of genetic and environmental factors in the etiology of hypertension / J. Kunes, J. Zicha // Physiol Res. - 2009. - No 58, Suppl 2. - S. 33-41.

15. Health risks and benefits from calcium and vitamin D supplementation: Women's Health Initiative clinical trial 
Огляди літератури, оригінальні дослідження, погляд на проблему, ювілеї

and cohort study / R. L. Prentice, M. B. Pettinger, R. D. Jackson [et al.] // Osteoporos. Int. - 2013. - Vol. 24 (2). - P. 567-580.

16. Institute of Medicine (US) Committee to Review Dietary Reference Intakes for Vitamin D and Calcium /
A. C. Ross, C. L. Taylor, A. L. Yaktine [et al.] // Dietary Reference Intakes for Calcium and Vitamin D. - 2011. - Washington (DC): National Academies Press (US); 2011. Available from: http://www.ncbi.nlm.nih.gov/books/NBK56070.

\section{REFERENCES}

1. Atsel, Ye.A. (2014). Effektivnost obrazovatelnykh programm v povyshenii kompetentnosti vracha v voprosakh diagnostiki i lecheniya arterialnoy gipertenzii [Efficiency of educational programs in increasing the competence of the doctor in the questions of diagnosis and treatment of arterial hypertension]. Spravochnik vracha obshchey praktiki Directory of the Doctor of General Practice, 3, 82-83 [in Russian].

2. Babinets, L.S., Kvasnitska, O.S., Mihenko, L.M., \& Pinkevych, O.Ya. (2011). Osteodefitsyt i vplyv suputnoi patolohii na yoho hlybynu pry khronichnomu pankreatyti [Osteodeficiency and the effect of concomitant pathology on its depth in chronic pancreatitis]. Bukovynskyi medychnnyi visnyk Bukovyna Medical Bulletin, 15, 2 (58), 183-185 [in Ukrainian].

3. Vertkin, A.L., Vertkin, A.L., Morgunova, L.Yu., \& Naumova, A.V. (2007). Osteoporoz u patsiyentov s somaticheskoy patologiyey v zavisimosti ot pola [Osteoporosis in patients with somatic pathology depending on sex]. Osteoporoz i osteopatologiya-Osteoporosis and Osteopathology, 1, 25-28 [in Russian].

4. Yena, L.M. (2015). Vozrast kak znachimyy komponent diagnostiki vtorichnykh gipertenziy [Age as a significant component of the diagnosis of secondary hypertension]. Arterialnaya gipertenziya - Arterial Hypertension, 4, 42-51 [in Russian].

5. Kovaleva, O.N. (2014). Hlyukometabolicheskie narusheniya i serdechno sosudystyy risk [Glucometabolic disorders and cardiovascular risk]. Ukrainska shkola endokrynolohii - Ukrainian School of Endocrinology, 63-73 [in Russian].

6. Kovalenko, V.M., \& Kornatskyi, V.M. (2014). Khvoroby systemy krovoobihu yak medyko-sotsialna i suspilnopolitychna problema [Diseases of the circulatory system as a medical and social and socio-political problem]. Analitychno-statystychnyi posibnyk - Analytical and Statistical Manual, 279 [in Ukrainian].

7. Litovskiy, I.A., \& Gordienko, A.V. (2013). Ateroskleroz i gipertonicheskaya bolezn. Voprosy patogeneza, diagnostiki i lecheniya [Atherosclerosis and hypertension. Questions of pathogenesis, diagnosis and treatment]. SpetsLit, 312 [in Russian].

8. Pasiyeshvili, L.M. (2016). Rol khronicheskogo pankreatita v narushenii metabolizma kostnoy tkani i formirovanii osteoporoza [The role of chronic pancreatitis in the disturbance of bone tissue metabolism and the formation of osteoporosis]. Visnyk VDNZU "Ukrainska medychna stomatolohichna akademiia" Aktualni problemy suchasnoi medytsyny - Bulletin of Higher State Ebucational Establishment "Ukrainian Medical Dentistry Academy" Actual Problems of Modern Medicine, 16, 4 (56), 166-169 [in Russian].

9. Sirenko, Yu.N., Gorbas, I.M., \& Andriyevskaya, S.A. (2014). Effektivnost i bezopasnost kombinirovannoy terapii na osnove khlortalidona i atenolola v odnoy tabletke (tenorik) u patsiyentov s gipertonicheskoy boleznyu: pervyye rezultaty vseukrainskogo nauchno-issledovatelskogo proekta trus [Efficacy and safety of combined therapy based on chlorthalidone and atenolol in one tablet (tenorik) in patients with essential hypertension: the first results of the allUkrainian scientific research project trus]. Arterialnaya gipertenziya - Arterial Hypertension, 6 (38), 46-47 [in Russian].

10. Tkach, S.M. (2013). Prakticheskiye podkhody k diagnostike khronicheskogo pankreatita [Practical approaches to the diagnosis of chronic pancreatitis]. Suchasna gastroenterologia - Modern Gastroenterology, 1 (69), 136146 [in Russian].

11. Bergh, J.P., Geel, T.A., \& Geusens, P.P. (2012). Osteoporosis, frailty and fracture: implications for case finding and therapy. Nat. Rev. Rheumatol., 8 (3), 163-172.

12. Bernstein, C.N., \& Leslie, W. D. (2013). The pathophysiology of bone disease in gastrointestinal disease. Eur. J. Gastroenterol. Hepatol., 15 (8), 857-864.

13. Dugga, S.N., Purcell, C., \& Kilbane, M. (2015). An association between abnormal bone turnover, systemic inflammation, and osteoporosis in patients with chronic pancreatitis: a case-matched study. Am. J. Gastroenterol., 110 (2), 336-344.

14. Kunes, J., Zicha, J. (2009). The interaction of genetic and environmental factors in the etiology of hypertension. Physiol. Res., 58 (2), 33-41.

15. Prentice, R.L., Pettinger, M.B., \& Jackson, R.D. (2013). Health risks and benefits from calcium and vitamin D supplementation: Women's Health Initiative clinical trial and cohort study. Osteoporos. Int., 24 (2), 567-580.

16. Ross, A.C., Taylor, C.L., \& Yaktine, A. L. (2011). Institute of Medicine (US) Committee to Review Dietary Reference Intakes for Vitamin D and Calcium. Dietary Reference Intakes for Calcium and Vitamin D, Washington (DC): National Academies Press (US); Retrieved from: http://www.ncbi.nlm.nih.gov/books/NBK56070. 
Харьковский национальный медицинский университет ${ }^{1}$, Харьковская городская многопрофильная больница № $18^{2}$

РЕзЮМЕ. При обследовании 70 пациентов с хроническим панкреатитом (ХП) и гипертонической болезнью (ГБ) проведено исследование роли гена рецепторов витамина D в течении данных заболеваний. Установлено, что коморбидность нозологических форм чаще наблюдалась у лиц с наличием B-аллеля полиморфизма гена VDR $(84,3$ \%), в отличие от контроля $(75,7 \%)$ и группы пациентов с изолированным ХП (77,5 \%). Также при ХП и ГБ чаще формировались остеопоротические изменения (27,3\%), в отличие от группы сравнения, где таких больных было 10 \%. Показаны достоверные изменения в показателях содержания остеокальцина, имеющие зависимость от полиморфизма гена VDR.

КЛЮчЕВЫЕ СЛОВА: хронический панкреатит; гипертоническая болезнь; ген рецепторов витамина D; остеокальцин.

\title{
ASSOCIATION OF METABOLIC AND GENETIC MARKERS IN THE RISK OF DEVELOPMENT OF OSTEOPENIC CONDITIONS IN COMBINING CHRONIC PANCREATITIS AND HYPERTENSIVE DISEASE
}

\author{
@L. M. Pasieshvili' ${ }^{1}$, T. I. Viun ${ }^{1}$, E. A. Lazutkina² \\ Kharkiv National Medical University ${ }^{1}$ \\ Kharkiv City Multidisciplinary Hospital No. $18^{2}$
}

SUMMARY. In the current research, 70 patients with chronic pancreatitis (CP) and hypertensive disease (HD) were examined for the role of the vitamin $D$ receptor gene during these diseases. It was found out that the comorbidity of nosological forms was more often observed in persons with the V-allele of polymorphism of the VDR gene (84.3 \%), unlike the control (75.7 \%) and the group of patients with isolated CP (77.5 \%). Also, with CP and HD, osteoporotic changes were most often formed (27.3\%), in contrast to the comparison group, where there were $10 \%$ of such patients. Significant changes are shown in osteocalcin content indicators, which depend on the polymorphism of the VDR gene.

KEY WORDS: chronic pancreatitis; hypertensive disease; vitamin D receptor gene; osteocalcin.

Отримано 17.02.2018 